\title{
PERANCANGAN APLIKASI EDUKASI PENGENALAN FAUNA ENDEMIK INDONESIA BERBASIS AUGMENTED REALITY
}

\author{
Muhammad Firman Ghozali ${ }^{1}$, Heri Satria Setiawan' ${ }^{2}$ Bayu Jaya Tama ${ }^{3}$ \\ Program Studi Teknik Informatika, Fakultas Teknik dan Ilmu Komputer, \\ Universitas Indraprasta PGRI \\ Jalan Raya Tengah No 80, Kelurahan Gedong, Pasar Rebo, Jakarta Timur \\ firmanghz19@gmail.com¹, herisatria20@gmail.com ${ }^{2}$, baja134@gmail.com ${ }^{3}$
}

\begin{abstract}
Abstrak
Penelitian ini mengkaji tentang kurangnya media pembelajaran yang interaktif untuk memperkenalkan fauna endemik Indonesia. Seiring dengan perkembangan zaman, saat ini terdapat banyak metode pembelajaran yang memanfaatkan kecanggihan teknologi dalam penerapannya, salah satunya adalah teknologi Augmented Reality. Augmented Reality merupakan teknologi yang menggabungkan benda maya dua dimensi dan ataupun tiga dimensi ke dalam sebuah lingkungan nyata tiga dimensi lalu memproyeksikannya secara real time. Tujuan penelitian ini adalah untuk merancang aplikasi pengenalan fauna endemik Indonesia dengan menerapkan teknologi Augmented Reality. Metodologi yang digunakan dalam penelitian ini adalah Grounded Research, yaitu metodologi penelitian kualitatif yang menekankan penemuan teori dari data observasi empirik di lapangan dengan metode induktif. Hasil penelitian ini diharapkan dapat menambah wawasan mengenai fauna endemik Indonesia serta memberi pengalaman pengguna (User Experience) tentang teknologi Augmented Reality.
\end{abstract}

Kata Kunci: Media Pembelajaran, Teknologi, Augmented Reality, Fauna Endemik Indonesia

\begin{abstract}
This study examines the lack of interactive learning media to introduce Indonesia's endemic fauna. Along with the times, there are currently many learning methods that utilize the sophistication of technology in its application, one of which is Augmented Reality technology. Augmented reality is a technology that combines two-dimensional and/or three-dimensional virtual objects into a three-dimensional real environment and then projects them in real time. The aim of this research is to design an application of recognition of Endemic Fauna of Indonesia by applying Augmented Reality technology. The methodology used in this study is Grounded Research, which is a qualitative research methodology that emphasizes the discovery of theories from e-deft observational data in the field with inductive methods. The results of this study are expected to add insight into Indonesia's endemic fauna as well as provide a user experience (User Experience) about Augmented Reality technology.
\end{abstract}

Keyword: Learning Media, Technology, Augmented Reality, Indonesian Endemic Fauna

\section{PENDAHULUAN}

Teknologi merupakan produk yang dihasilkan dan digunakan untuk memudahkan serta meningkatkan kinerja manusia. Salah satu kemajuan teknologi yang saat ini sedang berkembang pesat adalah Augmented Reality. Augmented Reality atau dalam bahasa Indonesia diterjemahkan menjadi Realitas Tambahan adalah sebuah teknik yang menggabungkan benda maya dua dimensi maupun tiga dimensi ke dalam sebuah lingkup nyata tiga dimensi. Benda-benda maya tersebut lalu diproyeksikan dalam waktu nyata (Pamoedji \& Maryuni, 2017). Objek yang ditampilkan Augmented Reality membantu pengguna dalam menghasilkan persepsi baru yang memungkinkannya berinteraksi dengan lingkungan nyata (Ismayani, 2020).

Sebagaimana kita ketahui, pada saat ini media pembelajaran pengenalan fauna endemik Indonesia masih banyak terbatas dalam bentuk buku yang hanya menampilkan gambar 2D saja. Setiap sisi dari bagian tubuh objek fauna tersebut tidak dapat dilihat secara detail, sedangkan apabila menggunakan alat peraga akan mengeluarkan biaya yang cukup mahal serta kurang fleksibel untuk dibawa kemana saja.

Atas dasar hal tersebut, peneliti memutuskan untuk membuat aplikasi dengan menerapkan Augmented Reality sebagai media pembelajaran interaktif untuk memperkenalkan fauna endemik 
Indonesia. Dengan demikian, diharapkan proses pembelajaran menjadi lebih atraktif serta memberi pengalaman pengguna (User Experience) tentang teknologi Augmented Reality.

\section{PENELITIAN RELEVAN}

Penelitian yang berhubungan dengan perancangan aplikasi edukasi pengenalan fauna endemik Indonesia berbasis Augmented Reality sudah pernah dilakukan oleh beberapa peneliti. Hasil penelitian tersebut peneliti gunakan sebagai acuan dalam proses perancangan aplikasi.

Penelitian relevan pertama dari (Saefudin \& Ekasari, 2017) dengan judul "Aplikasi Pembelajaran Fauna Endemik Indonesia Menggunakan Augmented Reality Berbasis Android". Rumusan masalah yang menjadi latar belakang penelitian ini adalah karena informasi bentuk pembelajaran pengenalan fauna endemik Indonesia dalam buku hanya menampilkan bentuk dua dimensi, sehingga setiap sisi bentuk fauna tidak dapat dilihat, sedangkan apabila menggunakan mannequin anatomi bentuk fauna akan mengeluarkan biaya yang cukup mahal serta akan sulit untuk dibawa kemana saja. Tujuan penelitian ini adalah untuk membuat aplikai pengenalan fauna endemik Indonesia dengan menggunakan teknologi Augmented Reality. Metode penelitian yang digunakan terdiri dari 4 tahap, yaitu analisis, perancangan, uji coba, dan implementasi.

Penelitian relevan kedua dari (Apriyani \& Gustianto, 2015) dengan judul "Augmented Reality sebagai Alat Pengenalan Hewan Purbakala dengan Animasi 3D Menggunakan Metode Single Marker". Rumusan masalah yang menjadi latar belakang penelitian ini adalah karena saat ini untuk mempelajari hewan purbakala melalui pelajaran sejarah di sekolah hanya dilakukan hanya melalui sebuah buku dan gambar yang terdapat pada buku-buku dan alat peraga biasa, tetapi dengan menggunakan teknologi Augmented Reality diharapkan dalam pembelajarannya dapat membuat pelajaran sejarah terutama mengenai hewan purbakala dapat lebih menarik dan menyenangkan karena Augmented Reality dapat menjadi sebuah alat peraga virtualisasi hewan purbakala dalam bentuk 3D. Tujuan penelitian ini adalah untuk membuat alat pengenalan hewan purbakala dengan Animasi 3D berbasis Augmented Reality. Metode penelitian dalam pembuatan aplikasi ini cara kerja sistem secara garis besar yaitu berupa pembuatan arsitektur sistem, script program, model 3D dan aplikasi android.

\section{METODE PENELITIAN}

Metode penelitian adalah suatu cara ilmiah untuk mendapatkan data dengan tujuan kegunaan tertentu. Cara ilmiah berarti kegiatan penelitian itu didasarkan pada ciri-ciri keilmuan yaitu rasional, empiris, dan sistematis (Darmadi, 2013). Metode penelitian merupakan suatu cara atau jalan untuk memperoleh kembali pemecahan terhadap permasalahan (Subagyo, 2015).

Pada penelitian ini metode penelitian yang digunakan oleh peneliti adalah Grounded Research. Grounded Research adalah suatu metode kualitatif yang bertujuan menemukan teori baru. Dasar dari metode ini adalah ilmu-ilmu sosial dan metodologi. Pertanyaan utama yang hendak dijawab adalah teori apa yang muncul sesudah analisis data lapangan dilaksanakan (Conny, 2010). Grounded Research dilaksanakan dengan mengadakan data yang ada di lapangan, baik dalam perumusan masalah, membangun hipotesis maupun penarikan simpulan penelitian (Sanjaya, 2015). Desain penelitian yang digunakan oleh peneliti adalah Kualitatif Tentatif, yaitu dengan membuat rancangan sistem terlebih dahulu sebelum melakukan penelitian ke lapangan. Setelah proses penelitian masuk ke lapangan, desain penelitian dapat berubah secara fleksibel menyesuaikan dengan kondisi atau situasi lapangan yang dihadapi (Lapau, 2012).

Terdapat 6 tahap dalam rancangan kegiatan penelitian ini, yaitu:

1. Pengumpulan Data

2. Analisis Data

3. Perancangan Sistem

4. Pembuatan Aplikasi

5. Pengujian Aplikasi

6. Laporan Penelitian

Teknik pengumpulan yang dilakukan oleh peneliti untuk mendapatkan data-data serta informasi untuk mendukung hasil dari penelitian ini antara lain adalah:

\section{Observasi}


Observasi merupakan salah satu cara mengumpulkan data yang diperlukan dengan cara melakukan pengamatan dan meneliti secara langsung kegiatan yang akan diselidiki oleh peneliti.

2. Studi Pustaka

Proses pengumpulan data dilakukan dengan cara studi kepustakaan, yaitu dengan menghimpun informasi relevan dari sumber skripsi, karya ilmiah dan internet.

3. Dokumentasi

Dokumentasi adalah pengumpulan catatan tertulis tentang berbagai kegiatan atau peristiwa pada waktu yang lalu. Semua dokumen yang berhubungan dengan penelitian yang bersangkutan dicatat sebagai sumber informasi.

Analisis yang dilakukan oleh peneliti berfokus pada perangkat lunak meliputi informasi, fungsi masing-masing pada bagian sistem, cara kerja, antarmuka, lalu menyediakan perangkat dan teknik yang dapat membantu peneliti untuk menentukan kebutuhan melalui sistem point of sales dalam melakukan pengolahan data. Perangkat yang dimaksud adalah penggunaan diagram flowchart untuk menyusun daftar input, proses, dan output.

\section{HASIL DAN PEMBAHASAN}

\section{Struktur Navigasi}

Struktur navigasi berfungsi untuk menggambarkan dengan jelas hubungan dan rantai kerja seluruh elemen yang akan digunakan dalam aplikasi. Dengan menggambarkan struktur navigasi, pembuatan aplikasi dapat tersusun dengan sistematis dan mudah. Berikut adalah gambar struktur navigasi dari aplikasi yang telah dibuat:

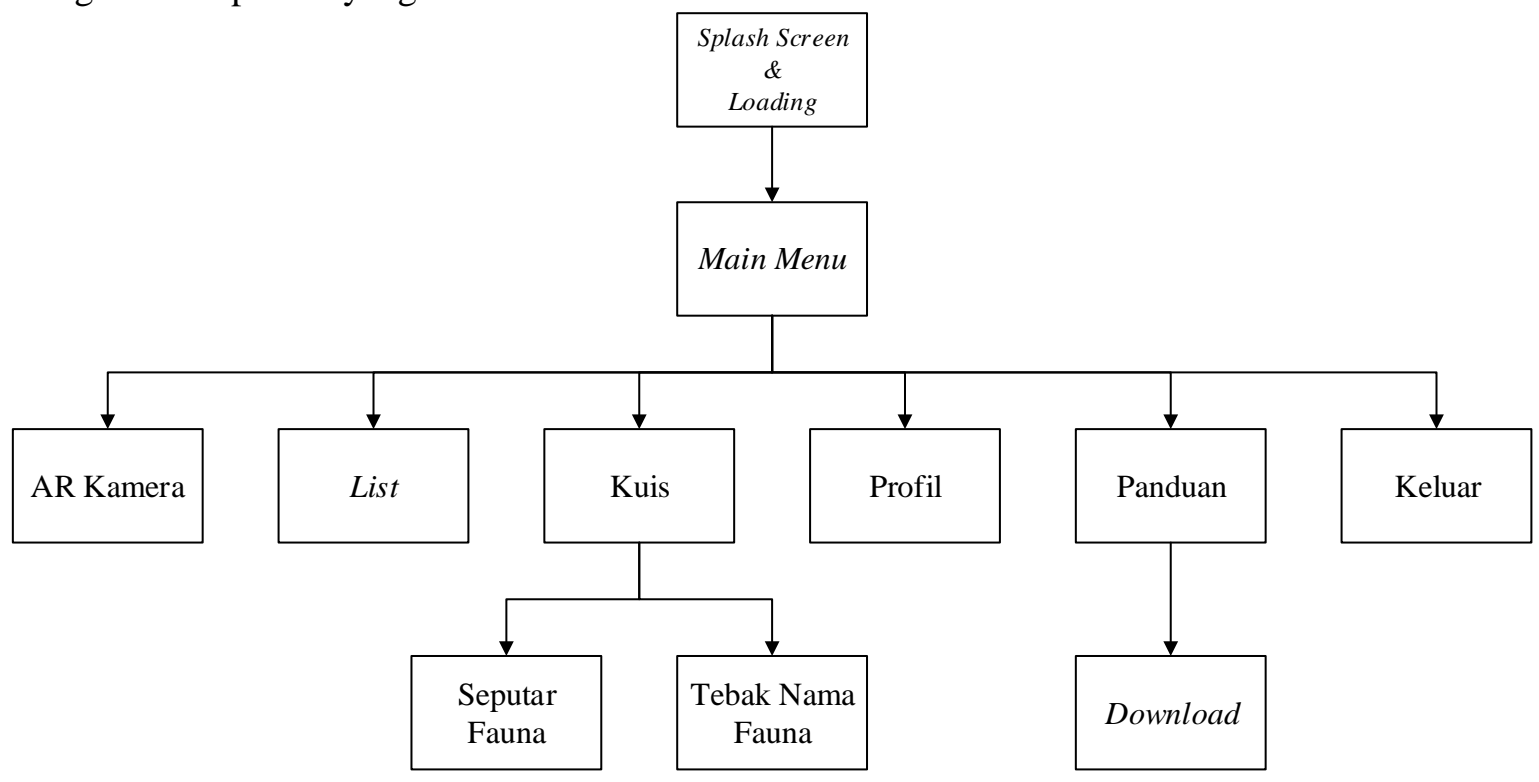

Gambar 1. Struktur Navigasi

\section{Flowchart}

Flowchart atau bagan alur merupakan metode untuk menggambarkan tahap-tahap penyelesaian masalah (prosedur) beserta aliran data dengan simbol-simbol standar yang mudah dipahami (Bonnie Soeherman, 2013). Berikut adalah Flowchart dari hasil pengembangan struktur navigasi yang telah dibuat: 


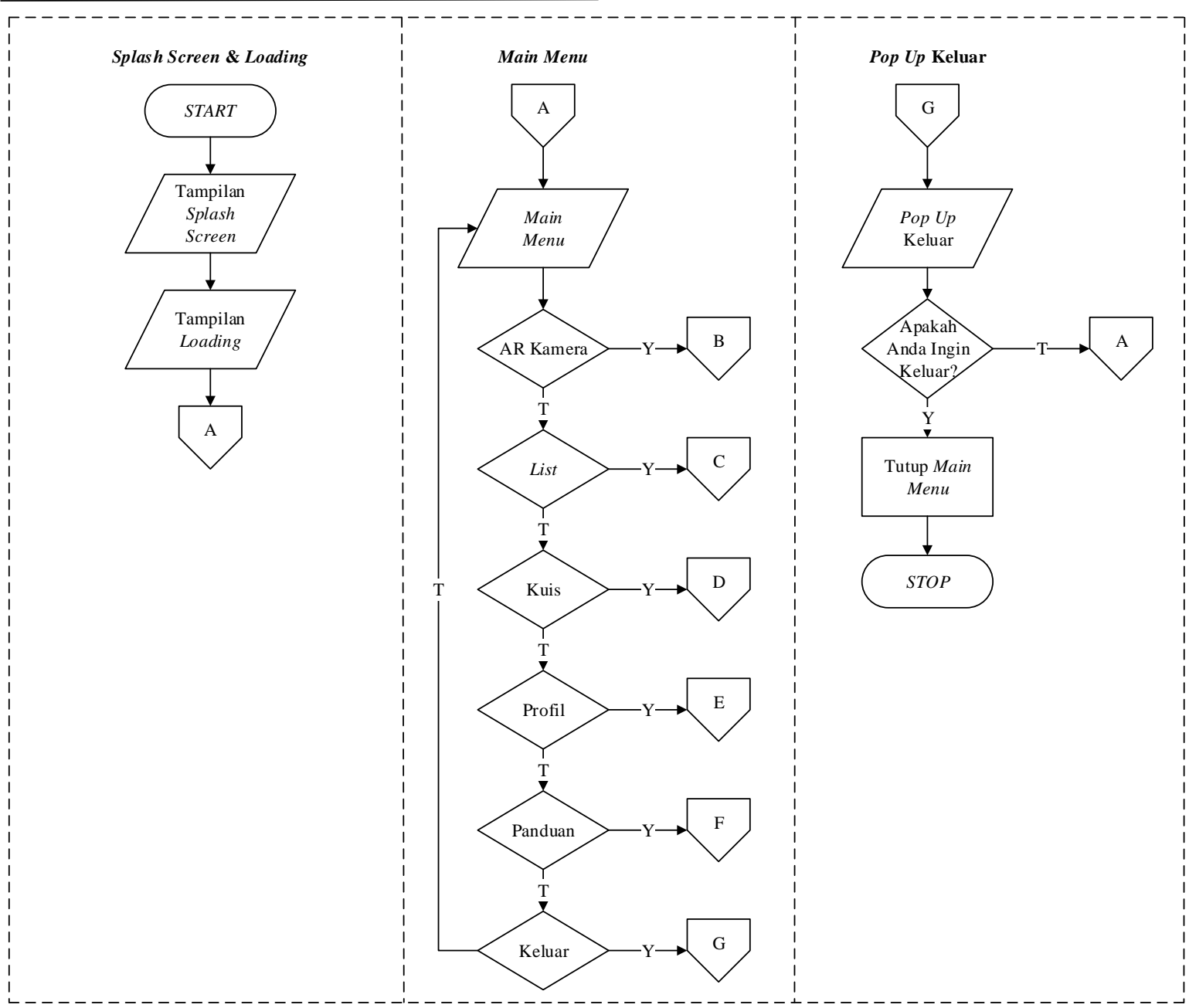

Gambar 2. Flowchart 1

Gambar Flowchart di atas merupakan pengembangan dari struktur navigasi yang telah dibuat. Penjelasannya adalah sebagai berikut:

1. Splash Screen \& Loading

Terminal Point "START" menandakan bahwa aplikasi mulai dijalankan. Tampilan awal aplikasi adalah Splash Screen, dilanjut dengan tampilan Loading, kemudian aplikasi melakukan proses untuk masuk ke dalam Main Menu. Tampilan Main Mепи selanjutnya dihubungkan dengan simbol konektor "A".

2. Main Menu

Main Menu diawali dengan konektor "A" yang merupakan lanjutan dari tampilan Splash Screen \& Loading. Terdapat 6 buah tombol di dalam Main Menu, yaitu tombol AR Kamera, List, Kuis, Profil, Panduan dan Keluar. Ketika dipilih, setiap tombol akan melakukan proses tertentu sesuai dengan fungsinya masing-masing. Kemudian pada akhir flowchart, setiap tombol diakhiri dengan simbol konektor sebagai penghubung proses dengan flowchart berikutnya.

3. Pop Up Keluar

Pop Up Keluar diawali dengan konektor "G" yang merupakan lanjutan dari tampilan Main Menu. Ketika tombol Keluar ditekan maka akan muncul kotak dialog yang menanyakan "Apakah Anda ingin keluar?" serta 2 buah tombol pilihan, yaitu tombol "Ya" dan "Tidak". Apabila tombol "Ya" dipilih maka aplikasi akan berhenti dan flowchart akan berakhir di terminal point "STOP". Sedangkan apabila tombol "Tidak" dipilih, maka Pop Up akan tertutup dan aplikasi kembali menuju Main Menu melalui konektor "A". 


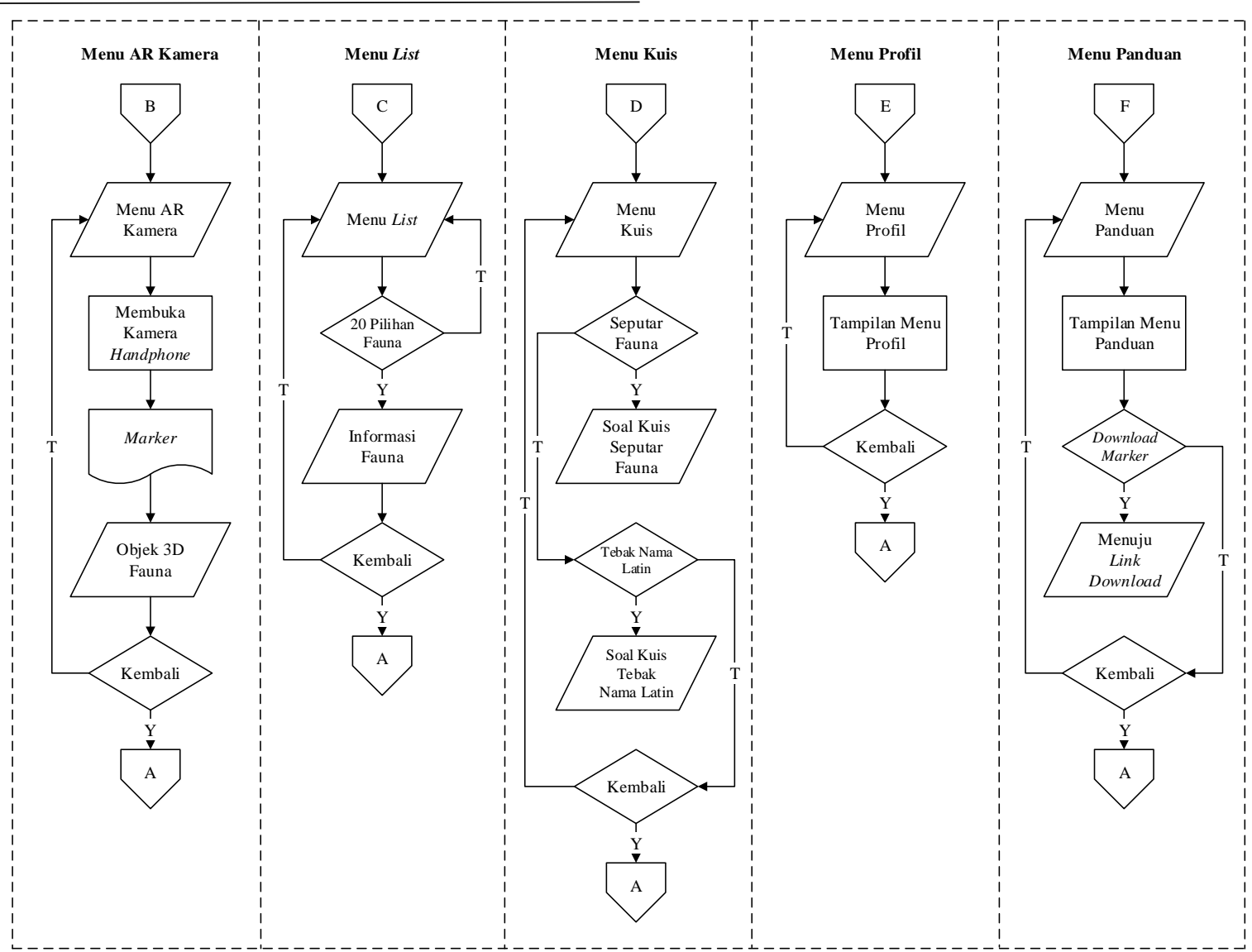

Gambar 3. Flowchart 2

Gambar Flowchart di atas merupakan penjabaran dari Flowchart Main Menu. Penjelasannya adalah sebagai berikut:

1. Menu AR Kamera

Menu AR Kamera diawali dengan konektor "B" yang merupakan lanjutan dari tampilan Main Menu. Ketika masuk ke dalam menu AR Kamera, proses pertama yg dilakukan adalah membuka kamera handphone. Selanjutnya kamera akan melakukan proses scan terhadap marker yang tersedia. Setelah marker terdeteksi, maka secara otomatis akan muncul objek 3D fauna. Selain itu juga terdapat tombol Kembali yang berfungsi untuk mengakhiri proses pada menu AR Kamera, serta membawa aplikasi kembali menuju Main Menu melalui konektor "A".

2. Menu List

Menu List diawali dengan konektor "C" yang merupakan lanjutan dari tampilan Main Menu. Pada menu List, terdapat 20 tombol Pilihan Fauna yang akan menampilkan Informasi Fauna tertentu ketika dipilih. Selain itu juga terdapat tombol Kembali yang berfungsi untuk mengakhiri proses pada menu List, serta membawa aplikasi kembali menuju Main Menu melalui konektor "A".

3. Menu Kuis

Menu Kuis diawali dengan konektor "D" yang merupakan lanjutan dari tampilan Main Menu. Ketika masuk ke dalam menu Kuis, terdapat 2 tombol pilihan kategori kuis, yaitu Seputar Fauna dan Tebak Nama Latin. Masing-masing tombol akan menampilkan soal kuis sesuai dengan kategorinya. Selain itu juga terdapat tombol Kembali yang berfungsi untuk mengakhiri proses pada menu Kuis, serta membawa aplikasi kembali menuju Main Menu melalui konektor "A".

4. Menu Profil

Menu Profil diawali dengan konektor "E" yang merupakan lanjutan dari tampilan Main Menu. Ketika masuk ke dalam menu Profil, terdapat informasi dan profil singkat dari pengembang 
aplikasi. Selain itu juga terdapat tombol Kembali yang berfungsi untuk mengakhiri proses pada menu Kuis, serta membawa aplikasi kembali menuju Main Menu melalui konektor "A".

5. Menu Panduan

Menu Panduan diawali dengan konektor "F" yang merupakan lanjutan dari tampilan Main Menu. Ketika masuk ke dalam menu Panduan, terdapat tombol Download Marker untuk mengunduh marker yang diperlukan. Selain itu juga terdapat tombol Kembali yang berfungsi untuk mengakhiri proses pada menu Kuis, serta membawa aplikasi kembali menuju Main Menu melalui konektor "A".

\section{Tampilan Aplikasi}

Berikut ini adalah tampilan layar dari aplikasi yang telah dibuat:

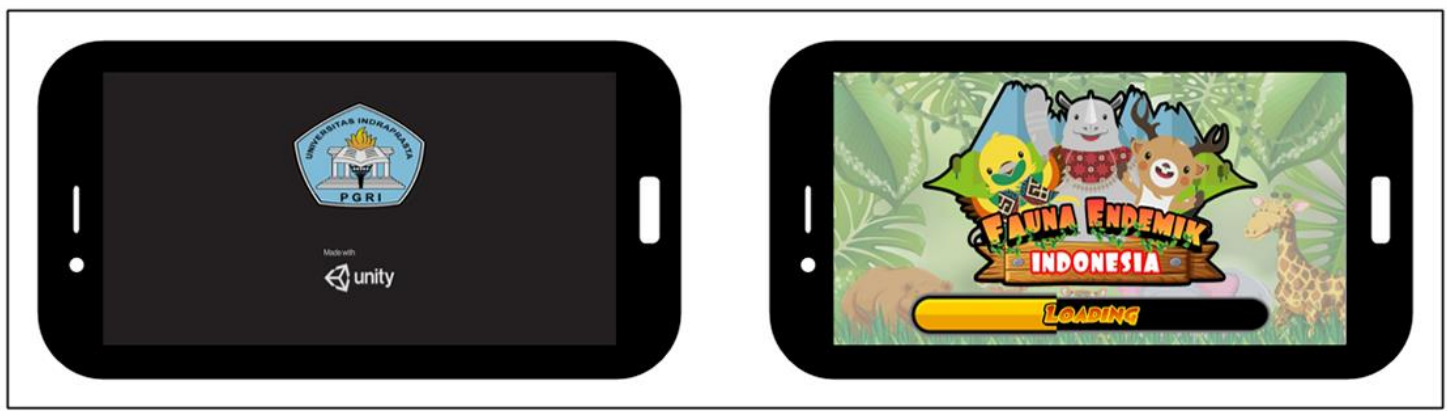

Gambar 4. Tampilan Splash Screen \& Loading

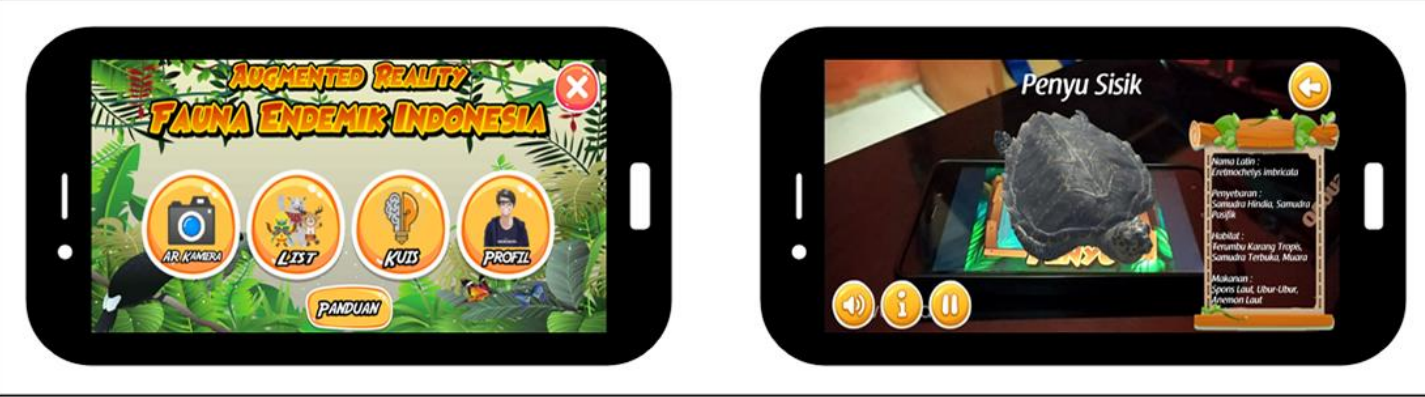

Gambar 5. Tampilan Main Menu \& AR Kamera

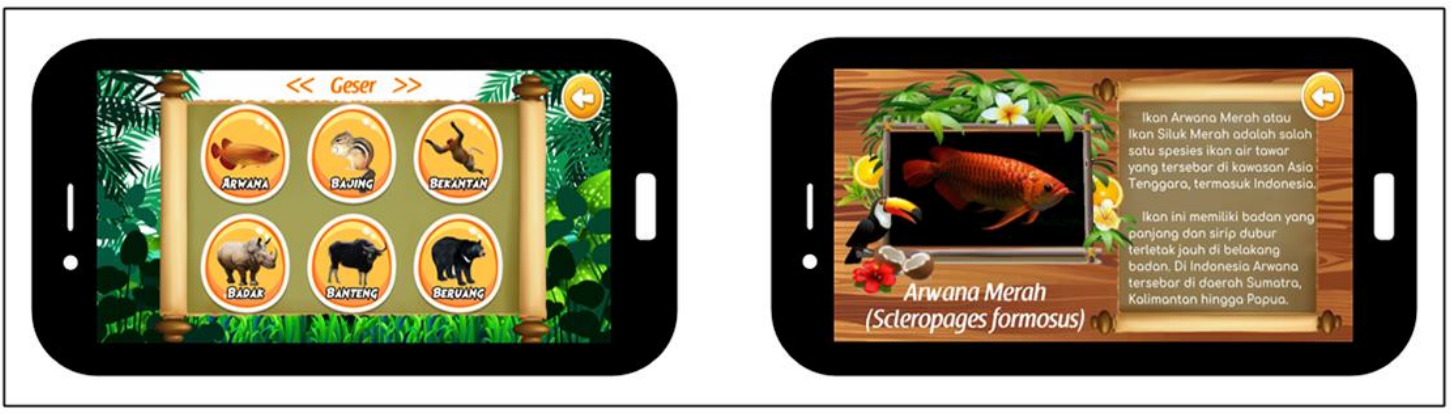

Gambar 6. Tampilan List 


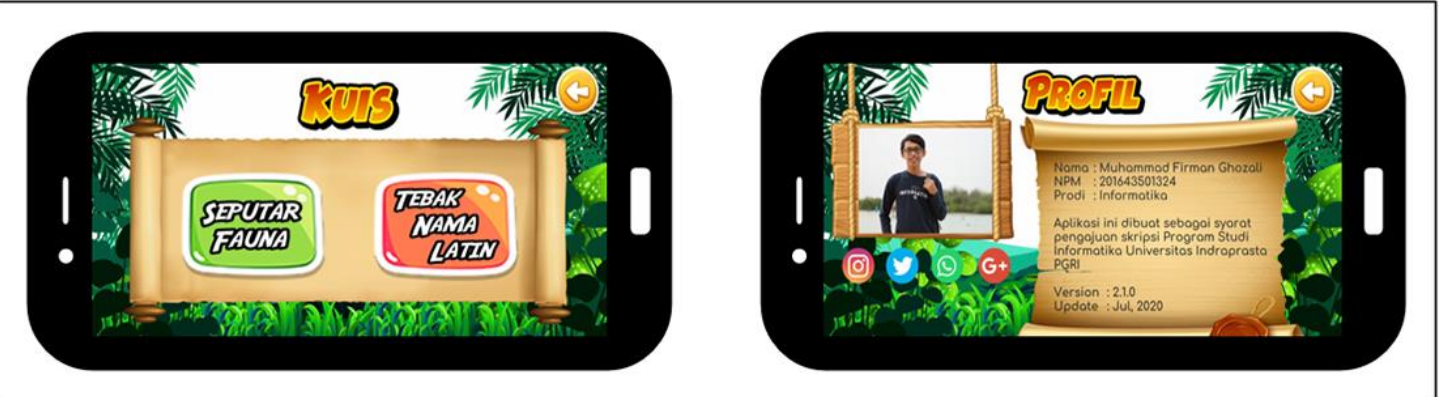

Gambar 7. Tampilan Kuis \& Profil

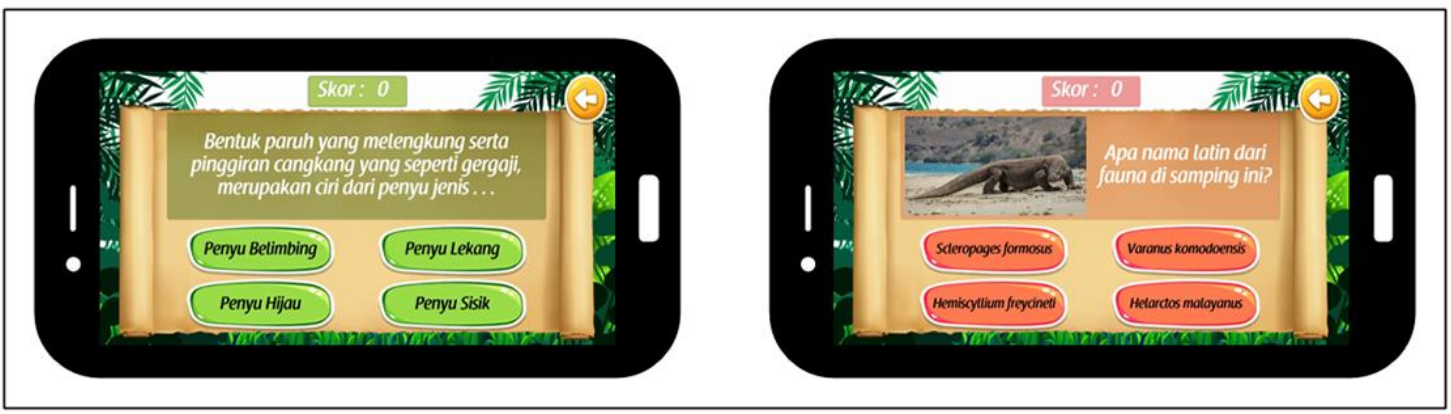

Gambar 8. Tampilan Soal Kuis

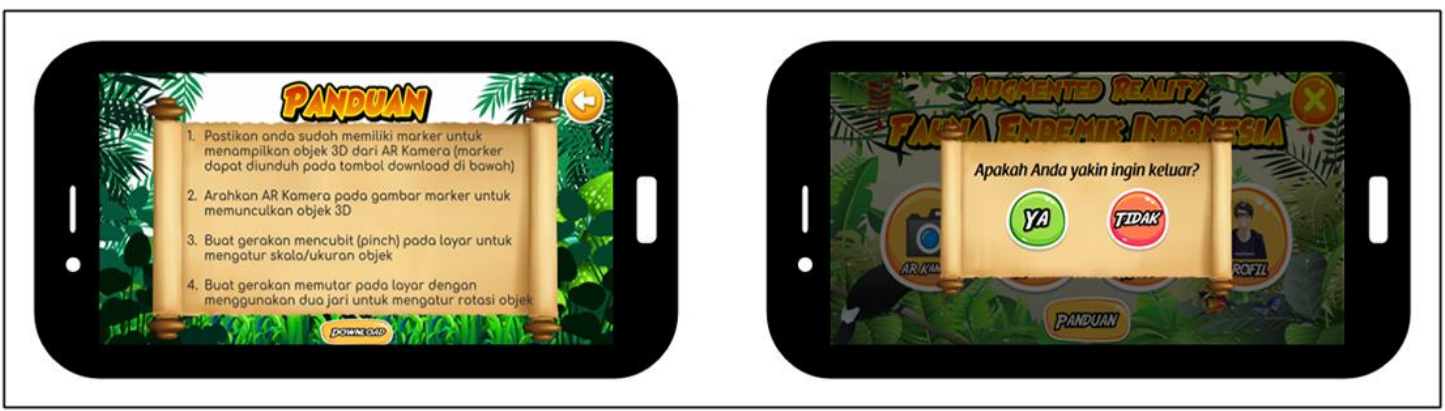

Gambar 9. Tampilan Panduan \& Pop Up Keluar

\section{Hasil Uji Coba}

Peneliti telah melakukan pengujian aplikasi "Augmented Reality Fauna Endemik Indonesia.apk" terhadap beberapa tipe handphone dengan versi Android yang berbeda-beda. Hasilnya adalah sebagai berikut:

\begin{tabular}{|c|c|c|c|c|c|c|c|}
\hline No & Merek & Tipe & Versi OS & Instalasi & $\begin{array}{c}\text { Kualitas } \\
\text { Gambar }\end{array}$ & $\begin{array}{c}\text { Tampilan } \\
\text { Layout }\end{array}$ & Error \\
\hline 1 & Oppo & F5 & 7.1 .1 & Berhasil & Baik & Baik & Tidak Ada \\
\hline 2 & Redmi & Note 8 & 9.0 .1 & Berhasil & Baik & Baik & Tidak Ada \\
\hline 3 & Vivo & Y57 & 6.0 .1 & Berhasil & Baik & Baik & Tidak Ada \\
\hline 4 & Xiaomi & Redmi 2 & 4.4 .4 & Berhasil & Baik & Baik & Tidak Ada \\
\hline 5 & Xiaomi & Redmi $3 \mathrm{~S}$ & 6.0 .1 & Berhasil & Baik & Baik & Tidak Ada \\
\hline
\end{tabular}

Dari hasil uji coba tersebut, aplikasi berhasil diinstal dan berjalan dengan baik pada 5 buah sampel uji coba handphone. Mulai dari versi Android terendah 4.4.4 sampai dengan versi Android tertinggi 9.0.1 aplikasi dapat berjalan dengan lancar tanpa terkendala. Kelima sampel handphone menunjukkan kualitas gambar dan tampilan layout yang sama baiknya. Dari semua sampel uji coba 
menunjukkan bahwa aplikasi dapat berjalan dengan baik dan berfungsi dengan semestinya tanpa adanya error.

\section{SIMPULAN}

Berdasarkan hasil perancangan sistem yang telah peneliti lakukan, diharapkan aplikasi "Augmented Reality Fauna Endemik Indonesia.apk" ini bisa menjadi media pembelajaran interaktif yang dapat meningkatkan minat pengguna untuk mengenal fauna endemik Indonesia. Dengan adanya aplikasi ini juga dapat mengefisien pembelajaran dan mengatasi keterbatasan penggunaan media buku. Selain itu pengguna aplikasi juga dapat memperoleh pengalaman pengguna (User Experience) tentang teknologi Augmented Reality.

Aplikasi ini memiliki berbagai macam fitur yang dapat menunjang kemudahan dalam penggunaannya, di antaranya adalah:

1. Terdapat fitur Multi-Touch Gestrures untuk mengatur perbesaran dan perputaran posisi objek 3D.

2. Terdapat tombol suara fauna dan tombol suara informasi.

3. Terdapat list fauna yang menampilkan foto, nama latin, serta informasi singkat seputar fauna.

4. Terdapat fitur kuis "Seputar Fauna" dan "Tebak Nama Latin" untuk mengasah kemampuan dan pengetahuan dari pengguna.

Aplikasi ini dibuat untuk memudahkan pengguna dalam mengakses informasi seputar fauna endemik Indonesia melalui handphone Android secara efektif dan mudah.

\section{DAFTAR PUSTAKA}

Apriyani, M. E., \& Gustianto, R. (2015). Augmented Reality sebagai Alat Pengenalan Hewan Purbakala dengan Animasi 3D Menggunakan Metode Single Marker. Jurnal INFOTEL, 7(1), 47-52.

Bonnie Soeherman, M. (2013). Designing Information System. Jakarta: Elex Media Komputindo.

Conny, R. S. (2010). Metode Penelitian Kualitatif. Jakarta: PT. Gramedia Widiasarana Indonesia.

Darmadi, H. (2013). Metode Penelitian Pendidikan dan Sosial. Bandung: Alfabeta.

Ismayani, A. (2020). Membuat Sendiri Aplikasi Augmented Reality. Jakarta: Elex Media Komputindo.

Lapau, B. (2012). Metode Penelitian Kesehatan: Metode Ilmiah Penelitian Skripsi, Tesis, dan Disertasi (Edisi Revisi). Jakarta: Yayasan Pustaka Obor Indonesia.

Pamoedji, A. K., \& Maryuni, R. S. (2017). Mudah Membuat Game Augmented Reality (AR) dan Virtual Reality (VR) dengan Unity $3 D$. Jakarta: Elex Media Komputindo.

Saefudin, M., \& Ekasari, M. H. (2017). Aplikasi Pembelajaran Fauna Endemik Indonesia Menggunakan Augmented Reality Berbasis Android. Jurnal SIMETRIS, 8(1), 27-34.

Sanjaya, W. (2015). Penelitian Pendidikan: Metode, Pendekatan, dan Jenis. Jakarta: Kencana.

Subagyo, J. (2015). Metode Penelitian dalam Teori dan Praktik. Jakarta: Rineka Cipta. 